
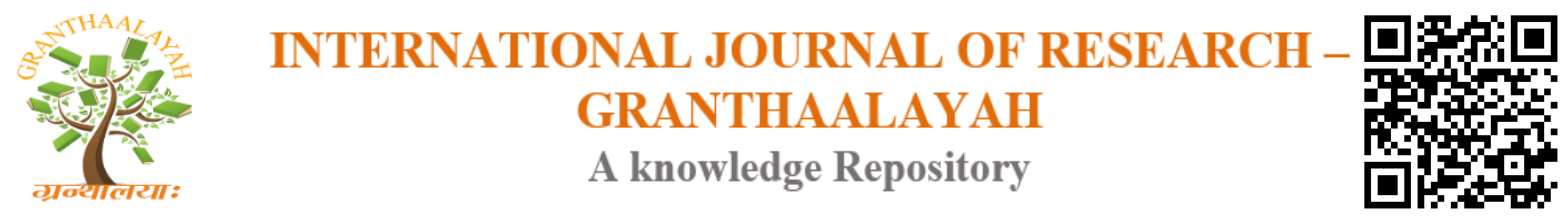

Management

\title{
ACCOUNTABILITY OF MADRASAH SUPERVISORS IN CAREER DEVELOPMENT HEAD OF MADRASAH TSANAWIYAH NEGERI IN JAMBI PROVINCE
}

\author{
Mukhtar $^{1}$, Risnita ${ }^{2}$, Edy Kusnadi ${ }^{3}$ \\ ${ }^{1}$ Professor at State Islamic University Sulthan Thaha Saifuddin Jambi Indonesia \\ ${ }^{2}$ Deputy Director of Postgraduate and Lecturers at State Islamic University Sulthan Thaha \\ Saifuddin Jambi Indonesia \\ ${ }^{3}$ Lecturers at State Islamic University Sulthan Thaha Saifuddin Jambi Indonesia
}

\begin{abstract}
This research is motivated by the pessimism of the Head of Islamic Education in improving their careers to a higher level. This situation is inseparable from the role and guidance carried out by the Madrasah supervisor. This study aims to: 1) Know the supervision of Madrasah that have not been accountable in fostering the career of the head of the Madrasah Tsanawiyah Negeri in Jambi Province. 2) Determine the accountability of supervisors of Madrasah Tsanawiyah Negeri in Jambi Province. 3) Knowing the career of the head of the Madrasah Tsanawiyah Negeri in Jambi Province. 4) Knowing the accountability of madrasah supervisors in the career development of Madrasah heads in Jambi Province.The research approach used is a descriptive qualitative approach. The technique of collecting data uses observation, interviews, and documentation. Data analysis using the Creswell model and data validity techniques using data triangulation.

The results of the research on the accountability of madrasah supervisors can be seen from the existence of transparency, liability, controllability, responsibility, responsiveness, ability, development, skills, training, and care. Career Head of Madrasah can be seen from the implementation of the stages of planning, growth, direction, exploration, development, stabilization, innovative work, professional ability, promotion, promotion, and appreciation. The conclusion is that the accountability of madrasah supervisors can develop the career of the Head of the Public Madrasah Tsanawiyah in Jambi Province. The implication of this study is that the accountability of madrasah supervisors is able to develop the career of the Madrasah Chief.
\end{abstract}

Keywords: Accountability of Madrasah Supervisors; Career Development.

Cite This Article: Mukhtar, Risnita, and Edy Kusnadi. (2019). "ACCOUNTABILITY OF MADRASAH SUPERVISORS IN CAREER DEVELOPMENT HEAD OF MADRASAH TSANAWIYAH NEGERI IN JAMBI PROVINCE." International Journal of Research - Granthaalayah, 7(7), 173-182. https://doi.org/10.29121/granthaalayah.v7.i7.2019.745. 


\section{Introduction}

Accountability is the condition of a person who is judged by others because of the quality of his performance in completing a goal that is responsible, credible, and gives satisfaction to interested parties to provide quality assurance (Syaiful Sagala, 2009 ) Accountability is regulated through the internalization of group values and pressures. Responsibility will improve self-managed (Gary Yukl, 2010).

The implementation of the aforementioned provisions is stipulated by the Decree of the State Minister for Administrative Reform and Bureaucratic Reform Number 21 of 2010 concerning Supervisory Functional Position and Credit Figures, and Decree of the Minister of Education and Culture Number 143 of 2014, concerning Technical Guidelines for Implementation of Supervisory Functional Position and Credit Figures. Education supervisors have a very strategic role in the framework of education quality assurance, especially in the formal education pathway. The main tasks and functions of supervisors as supervisors have a positive influence on improving the quality of education.

The legal basis of supervision, refers to Minister of Education Regulation No. 12 of 2007 concerning School / Madrasah Supervisory Standards, contains descriptions of personality competencies, managerial supervision competencies, academic supervision competencies, educational evaluation competencies, research development competencies and social competencies, as well as referring to 8 national education standards (Permendiknas No. 19 of 2005) (Permendiknas No. 19 of 2005) and some sweets that follow it: Content Standards, Process Standards, Competency Standards for Graduates, Educator and Tendik Standards, Infrastructure Standards, Management Standards, Financing Standards, and Standards Assessment, the legal basis is used as a reference for the implementation of school supervision activities. In education, supervision is an integral part of efforts to improve learning achievement and school quality.

The principal as the main person in charge of school success needs to improve his performance as a leader, supervisor, as well as other educational components / personnel. Apart from that it must be supported by career advancement. The success or failure of efforts to improve the quality of education is largely determined by the leadership ability of the principal and the ability of the teacher to carry out the main tasks as managers of school learning activities. Given the importance of the role of the principal in an effort to improve the quality of education, it is appropriate for the ability of the principal to be fostered through a continuous coaching program to truly possess the abilities demanded by professional demands. This has been regulated in the Minister of National Education Regulation of the Republic of Indonesia No. 13/2007 concerning Standards for Principals / Madrasas, namely regarding the Qualifications and Competency standards (Mulyasa, 2015).

One of the ways to guide the professionalism of principals in management management is to conduct supervision and guidance activities by professional school supervisors. Therefore the school supervisor plays a role in the career development of the principal. Thus the supervisor's responsibility is large enough for the good quality of education at school. Based on the results of data from the Ministry of Religion of Jambi Province, it can be seen that the Madrasah Tsanawiyah institutions found in Jambi Province are: 
Table 1: Total of MTsN and Supervisors of Madrasah Tsanawiyah in Jambi Province (Document of Regional Office of Ministry of Religion, 2017).

\begin{tabular}{|l|l|l|l|l|}
\hline NO & District and city & MTsN & MTsS & Supervisors \\
\hline 1 & Batanghari & 8 & 22 & 4 \\
\hline 2 & Bungo & 8 & 25 & 6 \\
\hline 3 & Kerinci & 7 & 19 & 9 \\
\hline 4 & Kota Jambi & 6 & 28 & 14 \\
\hline 5 & Sungai Penuh & 2 & 2 & 2 \\
\hline 6 & Merangin & 7 & 33 & 9 \\
\hline 7 & Muaro Jambi & 8 & 26 & 7 \\
\hline 8 & Sarolangun & 6 & 37 & 13 \\
\hline 9 & Tanjung Jabung Barat & 4 & 45 & 4 \\
\hline 10 & Tanjung Jabung Timur & 4 & 28 & 2 \\
\hline 11 & Tebo & 5 & 37 & 6 \\
\hline & Total & 65 & 302 & 76 \\
\hline
\end{tabular}

Based on the table above, there are 65 Madrasah Tsanawiyah Negeri (MTsN), and 302 Private Madrasah Tsanawiyah (MTsS), and there are 76 supervisors. In total there are 1011 Madrasah in Jambi Province, ranging from Madrasah Ibtidaiyah, MadrasahTsanawiyah and Madrasah Aliyah which are the responsibility of the supervisors as many as 76 people, consisting of 6 people from Kabupten Tebo, 2 people from Tanjung Jabung Timur, 4 people from Tanjung Jabung Barat, 13 people from Sarolangun, 7 people from Muaro Jambi, 9 people from Merangin, 2 people from Sungai Penuh City, 14 people from Jambi City, 9 people from Kerinci, 6 people from Bungo and 4 people from Batanghari. Based on these data, the researchers conducted a study in three regency areas, namely at Jambi MTsN 8 Outside the City of Muaro Jambi Regency, Batanghari District 1 MTsN, and at MTsN 1 Tebing Tinggi in Tebo Regency. The choice of location of the study is based on the area sociologically, ordinary people of Jambi Province divide the area into three namely upstream, middle and downstream. From the results of the survey on the 8th MTsN Outside the City of Jambi, interviews with the Head of the Madrasah explained that the Madrasah supervisors had the task of only supervising or controlling the implementation of the learning process and school administration then reporting to the Ministry of Religion. The supervisor does not have a special work program design for the Head of the Madrasah supervised in this case the leadership of the Madrasah head.

\section{Theoretical basis}

\subsection{Accountability of Madrasah Supervisors}

Lester R. Bittel cited by Mukhtar (Mukhtar and Iskandar, 2009) argues that accountability is an accountability, either personally or to subordinates who have been delegated by a leader, and it is the obligation of the organization or school that he is dismissed or authorized to carry out the task. Accountability can also be interpreted as a form of power, in accordance with authority and human rights.

Dealy, M. David and Andrew R Thomas suggest accountability is a relationship based on the obligation to demonstrate and accept responsibility for performance seen from the expectations 
that have been agreed upon. Accountability starts not from the outside but from within. The basic thing is high personal expectations (Dealy, M. David and Andrew R. Thomas, 2007). Gibson, James L suggests personal accountability shows one's responsibility for his work.

Accountability according to Mardiasmo, explains that the notion of accountability is: "Accountability is the obligation of the holder of the trust (agent) to provide accountability, present, report, and disclose all activities and activities that are his responsibility to the trustee (prinscipal) that has the right and the authority to hold this responsibility. "

According to Indra Bastian the term accountability can be interpreted as an obligation to convey accountability or to answer, explain the performance and actions of a person / legal entity / collective leader or organization to those who have the right or authority to hold accountable (Indra Bastian, 2010).

Accountability is all the components that drive the activities of the company, according to their respective duties and authorities (Suherman Toha, 2007). Accountability can be interpreted as the obligation of individuals or authorities entrusted to manage public resources and those concerned with them to be able to answer matters relating to their accountability. Accountability is closely related to instruments for control activities, especially in terms of achieving results in public services and conveying them transparently to the public.

Gerald A. Krines mentions that accountability plays a large role for individual values that contribute to the organization. The implementation of continuous, personal and atomistic transformation gets expectations to give expectations by the school as a whole that implies major steps for school staff and leaders (Knapp, Michael S. and Susan B. Feldman, 2012).

Relationship between work accountability and career was found by Susan L. Hersperger. Hersperger proposed an assessment of accountability in 5 years to improve one's career and technical education (Hersperger, Susan L., 2012). Koppel explained the concept of accountability in the 5 sections described as follows:

Table 2: Koppell's Concept of Accountability

\begin{tabular}{|l|l|}
\hline Conception of Accountability & Key determination \\
\hline Transparency & Demonstrate real performance \\
\hline Liability & Facing the consequences of performance \\
\hline Controllability & Carry out orders from superiors \\
\hline Responsibility & Follow the rules \\
\hline Responsiveness & Meet real expectations \\
\hline
\end{tabular}

The table above explains Koppell's accountability concept which is divided into five categories, namely transparency, being able to be responsible, able to control, be able to respond, and be willing to listen. The dimensions of accountability above accommodate management of individual and environmental expectations. Transparency and accountability are the foundations that underpin every manifestation of accountability. And there is a big relationship between the dimensions of control, responsibility, and responsiveness. 
Monitoring objectives in the guideline for implementing school supervisor / madrasah tasks The supervision objectives are: Supervising, Advice (advising), Monitoring (monitoring), Making reports on Reporting, Coordinating, and (Coordinating Lead) Development.

If someone carries responsibility, then the goals that need attention are: satisfactory work performance, recognition by others, loyalty to the organization, utilization of mentors and sponsors, subordinate support, utilization of opportunities to grow, stopping at the request and willingness of his own.

Job analysis is often called job analysis, task analysis, and activist analysis / work research. Systemically, job analysis collects data and makes consideration of all important information related to a particular job. The results of the job analysis are input to HR activists. Accountability of the supervisor has a duty to be a trainer, namely to train and develop skills and abilities to his subordinates or those who are the area of supervision.

Based on the explanation above, what is meant by accountability of madrasah supervisors is explaining performance and actions as the responsibility of supervisors of human resources (HR) in schools or madrasas in the implementation of education. Tasks as supervisor include: preparation of supervisory programs, implementing programs, supervising, evaluating results, as well as mentoring and training. The accountability indicators of madrasah supervisors are: transparency, liability, controllability, responsibility, and responsiveness.

\subsection{Career Development of Madrasah Heads}

Career is a job, therefore each individual is given the opportunity to do a job according to his capacity and abilities. In fulfilling the necessities of life, humans need a job, this is in accordance with the commands of Allah SWT in QS. At-Taubah: 105 (Ministry of Religion, 2006).

Career development is the realization of the relationship between individuals as workers and their organizations (Maisah, 2013). Then Osibanjo in Mukhtar, explained that career development as a business is continuously carried out by organizations in an effort to improve and enrich human resources to meetthe needs of workers and organizations (Mukhtar, et.al, 2016). However, employee development can be done with four types of strategies, namely: formal education, work experience, interpersonal relations and assessment.

The concept of career development can also be done with four phases, namely: self-introduction, development of various choices, focus on a choice, daring to take appropriate actions, which are in accordance with experience and ability, as can be described as follows: 


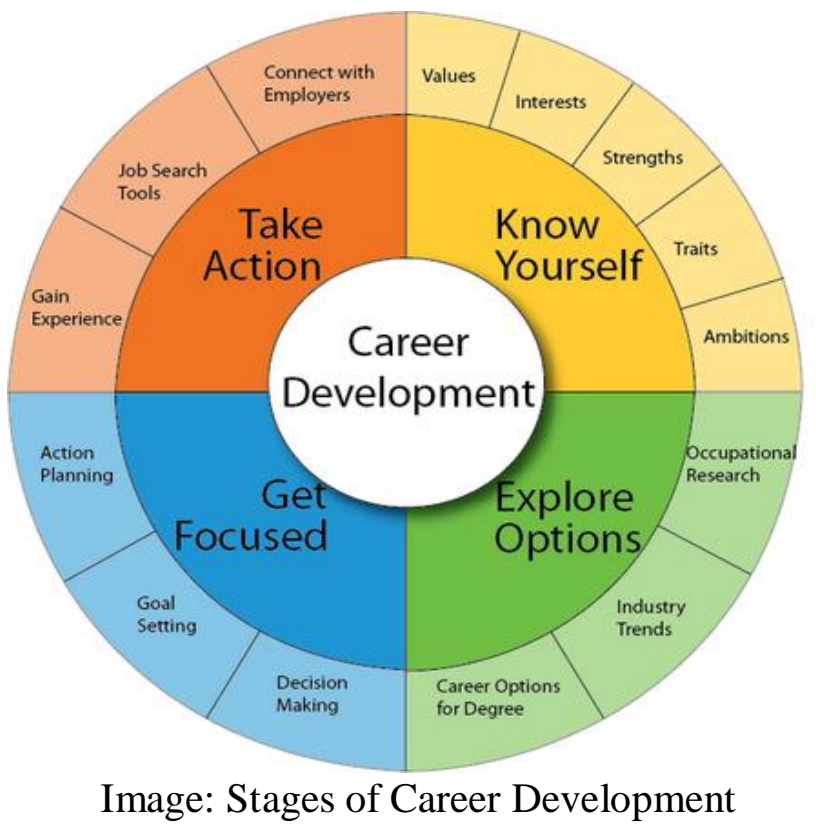

In the picture above, it gives an understanding that in career development, the steps taken are first to recognize oneself, in the sense of understanding the potential, talents and interests possessed, second is the development of various choices, in terms of recognizing the world of work and choosing according to the desired one, third is to focus on a choice, that is, after choosing one option, it must be fukus and serious in carrying it out, then fourth, that is, dare to take appropriate action and do the work better.

According to Wahjosumidjo (Wahyusumidjo, 1999) suggests that the principal is a functional teacher who is given the task of leading a school where a teaching and learning process is held, or a place where there is interaction between the teacher who gives lessons and students who receive the lesson.

Principals include formal leaders in educational institutions. Interpreted as head, because the principal is the highest official in the school. the principal is the main person in charge structurally and administratively at the school. Because the leader is different from a manager in a company (Veithzal Rivai Zainal, et.al, 2014).

In the career phase of human resources, the stages of one's career journey can be summarized as follows:

\section{1) Stage of growth}

This stage lasts more or less than at birth until someone is 14 years old, someone develops a personal image by identifying himself and interacting with other people, such as family, friends, and teachers.

\section{2) Exploration stage}

This stage takes place when a person has 15 years to 24 years.

\section{3) Stabilization stage}

This stage runs from someone 24 years to 44 years old, and this stage is the core work life of everyone in general. 
Three phases in designing a career development program. The following are three phases in designing a career development program:

\section{1) Planning Phase}

The planning phase is an activist aligning the design of the supervisor and design of the organization / company regarding career development in their environment.

\section{2) Direction Phase}

The function phase is intended to help employees be able to realize their plans into reality by establishing the type of career they want and managing the steps that must be taken to make it happen.

\section{3) Development Phase}

The development phase is the period of time that the employee uses to fulfill the requirements that allow him to move from another desired position. Employees must strive to realize their creativity and initiative that can support entering positions / positions in the future.

From several theories above, the researcher concludes that the head of an Islamic madrasa is the head of the madrasa who has the ability to become a motivator, innovator, educator, leader, manager, administrator and as a supervisor in all kinds of activities in the school, therefore the headmaster must have an understanding of characters / personality that is good, strong, professional in all fields, has knowledge and skills and has high motivation in developing teacher potential or quality of education. The indicators of the career development of the madrasa which are the goals that need attention are: planning, growth, direction, exploration, development, stabilization.

\section{Research Methodology}

The study of supervisory accountability in this study uses descriptive methods. This study seeks to describe and understand the accountability of madrasah supervisors in developing the career of the madrasa principals as they are in a rounded unity. In that sense, the approach used is qualitative, which is an approach to find answers to the questions why a phenomenon appears or something that is meaningful.

Creswel interpreted qualitative research in the form of methods to explore and understand the meaning derived from social problems involving important efforts such as asking questions and procedures collecting specific data from participants (Jhon W. Creswell, 2014). According to Creswell qualitative research is methods for exploring and understanding meanings by a number of individuals or groups of people ascribed to social or humanitarian problems (Jhon W. Creswell, 2010). Creswel explained that qualitative methodology can be carried out with a variety of approaches including: participatory research, discourse analysis, ethnography, grounded theory, case studies, phenomenology, and narrative.

The research approach is structured, planned and procedural ways to conduct a scientific study by combining all the potential and resources that have been prepared. The research approach is largely determined by the research paradigm, which is a perspective chosen by the researcher. The researcher used a grounded theory study approach, namely researchers applied the efforts of 
researchers to carry out abstract analysis of a phenomenon, with the hope that this analysis could create certain theories that could explain the phenomenon specifically.

\section{Discussion of Findings}

Based on the results of data analysis, researchers can conclude a number of things as follows:

1) Supervisors Madrasah Tsanawiyah have not been accountable in fostering the career of the head of the Madrasah Tsanawiyah Negeri in Jambi Province (MTsN1 Muara Bulian Batanghari, MTsN 8 Jambi Luar Muaro Jambi City, MTsN1 Tebing Tinggi Tebo) due to several things: lack of resources for supervisors. Funding in the scope of the supervisory program is very minimal, so the number of planned programs cannot work properly. Such as, the lack of guidance and guidance on improving HR careers, especially the career of the headmaster. So that supervisors only focus on academic supervision rather than managerial. Then in supporting the improvement of career guidance for the headmaster, it is constrained in self-development and scientific work due to the lack of training and low motivation in writing, so that the rank of the headmaster is on average at the IV / A level.

2) Accountability of the supervisors of the Public Islamic Education in Jambi Province (MTsN1 Muara Bulian Batanghari, MTsN 8 Jambi Luar Kota Muaro Jambi, MTsN1 Tebing Tinggi Tebo) in the implementation of managerial supervision refers to the basis of the Minister of National Education Regulation Number 13 of 2007 which consists of ten competencies namely: Arranging madrasa planning for various levels of planning. Developing madrasa organizations according to needs. Leading the madrasa in the context of utilizing madrasa resources. Manage change and development of madrasas towards learning organizations. As a managerial supervisor, the supervisor is obliged to help the head of the madrasah to achieve an effective madrasa, towards hearing quality education. Supervisors are obliged to assist qualified madrasa students by implementing a supervisory program that has been prepared, and evaluating the results of programs that have been implemented or have been held. Supervisors are to help madrassas to have good quality quality with transparency, liability, controlability, responsibility, and responsiveness, ability, development, skills, training, and care.

3) Career head of the Madrasah Tsanawiyah Negeri in Jambi Province (MTsN1 Muara Bulian Batanghari, MTsN 8 Jambi Luar Kota Muaro Jambi, MTsN1 Tebing Tinggi Tebo) which is determined by the success of Madrasah heads to madrasah managers with madrasa planning skills, madrasah management implementation, madrasa leadership and madrasa supervision. As for this, the career of the head of the madrasa can increase with the support of an increase in the rank / position / head of the madrasa. Based on research in the field, researchers see the implementation and achievement of self-development as evidenced by the ability possessed in the fields of education, interpersonal work relations, work experience, managerial competency, supervision competence, personal competence, social competence, entrepreneurial competence, and promotion. The headmaster's career is determined by satisfying work performance achieved through the stages of planning, growth, direction, exploration, stabilization, innovative work, professional ability, promotion, promotion, and appreciation.

4) Accountability of madrasah supervisors in the career development of Madrasah heads in Jambi Province (MTsN1 Muara Bulian Batanghari, MTsN 8 Jambi Luar Kota Muaro Jambi, MTsN1 Tebing Tinggi Tebo) in the context of educational change are elements that 
can provide enlightenment. Enlightenment is comprehensive in the school environment. The performance of supervisors, although technical in nature, has a strategic position in creating a conducive situation for the achievement of the performance of each element in the madrasa. The supervisory program guides the competencies of the madrasa principals, the performance of the principal, the performance appraisal of the principal, supervising, advising, monitoring, and reporting the development, reporting, coordinating, and performing (performing). leadership). And the achievement of self-development as evidenced by the capabilities possessed, namely innovative work, promotion / class, group IV / E, get promotion, salary / benefits / certification, and performance awards for those who excel.

\section{Conclusion}

The accountability of Madrasah supervisors in the career development of the Madrasah head is the Madrasah supervisor who applies transparency, liability, controllability, responsibility, responsiveness, ability, development, skills, training, and concern for the career development of the head of the madrasa resulting in satisfying work performance achieved through the stages of planning, growth, direction, exploration, stabilization, innovative work, professional ability, promotion, promotion, and appreciation.

\section{References}

[1] Dealy M. David dan Andrew R. Thomas. Managing by Accountability: What Every Leader Needs to Know about Responsibility, Integrityand Results. London: Praeger. 2007.

[2] Direktorat Tenaga Kependidikan. 2009.

[3] Dokumen.Bagian Perencanaan dan Sistem Informasi Kanwil Kemenag Provinsi Jambi.2017.

[4] Gary Yukl.Leadership in Organizations, 7th ed. New Jersey: Prentice Hall. 2010.

[5] Gibson, James L. Organizations: Behavior, Structure, Processes. New York: McGraw-Hill. 2012.

[6] Hersperger, Susan L. Career and Technical Education: The Impact of Program Investment on Accountability Ratings. United Stated: ProQuest,UMI Number 3531782, 2012.

[7] Hwang, Kwangseonthe Impact of Accountability and Accountability Management onPerformance at the Street Level. United Stated: ProQuest, UMI Number: 3585756. 2013.

[8] Indra Bastian. Akuntansi Sertor Publik: Suatu Pengantar. Jakarta: Erlangga. 2010.

[9] Jhon W. Creswell. Terjemahan Achmad Fawaid, Research Design Pendekatan Kualitatif, Kuantitatif dan Mixed. Yogyakarta: Pustaka Pelajar. 2014.

[10] Jhon W. Creswell. Terjemahan Achmad Fawaid, Research Design PendekatanKualitatif, Kuantitatif dan Mixed. Yogyakarta: Pustaka Pelajar. 2010.

[11] Kementrian Agama. Al-Qur'an dan Terjemahannya. Jakarta:CV.Pustaka Agung Harapan. 2006.

[12] Knapp, Michael S. dan Susan B. Feldman. Managing the Intersection of Internal and External Accountability "Challenge for Urban School Leadership in the United States", ed. Karen Seashore Louis. Journal of Educational Administration, Emerald Group, Vol. 50 No. 5, 2012, ISSN 0957 8234.

[13] Maisah. Manajemen Pendidikan. Jakarta: Referensi. 2013.

[14] Mukhtar dan Iskandar. Orientasi Baru Supervisi Pendidikan. Jakarta: Gaung Persada Pers. 2009.

[15] Mukhtar, et.al. Pengembangan Karir Tenaga Pendidik: Teori dan Aplikasi,Yokyakarta: Magnum Pustaka Utama. 2016.

[16] Mulyasa. Manajemen dan Kepemimpinan Kepala sekolah. Jakarta: Bumi Aksara. 2015.

[17] Permendiknas No. 19 tahun 2005. 
[18] Sedarmayanti. Perencanaan dan Pengembangan Sumber Daya Manusia: untu Meningkatkan Kompetensi, Kinerja, dan Produktivitas Kerja. Bandung: Refika Adimata. 2017.

[19] Suherman Toha.Penelitian Masalah Hukum tentang Penerapan Good Coorporate Governance Pada Dunia Usaha. Badan Pembinaan Hukum Nasional Departemen Hukum dan Hak Asasi Manusia RI. 2007.

[20] Syaiful Sagala.Kemampuan Profesional Guru dan Tenaga Kependidikan. Bandung: Alfabeta. 2009.

[21] Veithzal Rivai Zainal, et.al.Kepemimpinan dan Perilaku OrganisasiJakarta: Raja Grafindo Persada. Cet 11.2014.

[22] Wahyusumidjo, Kepemimpinan Kepala Sekolah, Tinjauan Teoritik dan Permasalahannya.Jakarta: Raja Grafindo Persada. 1999. 